\title{
The need for coordination of research activities in pediatric lung diseases
}

\author{
Harald Ehrhardt ${ }^{*}$ and Klaus-Peter Zimmer
}

During the recent years, the scientific knowledge of the pathomechanisms and new therapeutic options in pediatric lung diseases has dramatically increased which is reflected by the more and more increasing number of publications in this important field. Additionally, major scientific efforts have been bundled within national and international research networks like the German Center for Lung Research (DZL), the platforms of the European Respiratory Society (ERS), and the different Cooperation in Science and Technology (COST) actions [1, 2]. It was for the first time that the German Society for Pediatric and Adolescent Medicine (DGKJ) brought together international lung researchers in an English-speaking "DGKJ Scientific LUNG Symposium" at the annual meeting in Munich on September 3 and 4, 2016. The DGKJ invited frontiers in science covering important aspects of pediatric lung diseases to discuss their latest research findings with clinical experts in the field. The discussion of recent results from animal models and from molecular studies emphasized the need for an earlier and better exchange between basic research and clinical challenges of pediatrics to promote the translation of experimental results to patient care (and back) which was also recently promoted, i.e., by the scientific journal of the European Respiratory Society [3]. All together, the symposium demonstrated impressively the relevant similarities and overlaps of pathomechanisms between the broad spectrum of pediatric lung diseases which arouse from completely different origins including inborn, acquired, genetic, and environmental factors.

Pediatric lung disease already starts early in utero when the highly orchestrated process of lung development gets disturbed [4-7]. The balance of signaling pathways driving alveolar, mesenchymal, and vascular development including fibroblast growth factor 10 (FGF10) signal transduction, the transforming growth factor

\footnotetext{
* Correspondence: Harald.Ehrhardt@paediat.med.uni-giessen.de

Department of General Pediatrics and Neonatology, Center for Pediatrics and Youth Medicine, Justus-Liebig-University, Universities of Giessen and Marburg Lung Center (UGMLC), Member of the German Lung Research Center (DZL), Feulgenstr. 12, D-35392 Gießen, Germany
}

beta (TGF- $\beta$ ), hypoxia-inducible factors (HIF), vascular endothelial growth factor (VEGF-A), and vitamin Aretinoid signaling represents the prerogative for undisturbed alveolo- and vasculogenesis. Surprisingly, not only the overstimulation of central growth signaling pathways including the nuclear factor "kappa-lightchain-enhancer" of activated B cells (NFkB) pathway but also the reduced baseline activity, i.e., in the absence of a central regulatory cytokine-like tumor necrosis factor alpha (TNF- $\alpha)$ can aggravate lung damage $[4,6,7]$. The complexity of regulation is further enhanced by the post-transcriptional control of protein production by microRNAs. Although many studies were able to identify potential candidates, the proof of causality is still mostly missing [5]. The central link between pulmonary inflammation and distortion of lung development is modulated by amniotic infection and a bundle of wellestablished clinical therapies including steroid exposure as well as the avoidance of mechanical ventilation and high oxygen exposure $[6,8]$. Within the cell populations contributing to the development of chronic lung disease, mesenchymal stromal cells have attracted special attention during the recent years. Animal studies and a first human study showed a protective effect to the neonatal lung but a clear separation of the potential mechanisms of action including growth factor release, immunomodulation, and the substitution of injured cells is necessary before broad application within clinical trials $[9,10]$. We are just beginning to understand the long-term consequences for these patients $[6,11]$. During the presentations, it became clear that the major pediatric lung diseases like BPD, asthma, cystic fibrosis, and severe respiratory viral infections have common and distinct signaling pathways responsible for disease severity. Different genetic and epigenetic constellations, the exposure to certain environmental factors, and the heterogeneity of immune response determine the clinical phenotype of asthma, cystic fibrosis, and viral infections [12-17]. Even within a class of pathogens, the invader can take different endocytotic pathways and target 
different intracellular sites [16]. Despite the high complexity of immune reactions and pathomechanisms which might account for differences in phenotype and treatment responses, there are also promising results for potential candidates like granulocyte-macrophage colony-stimulating factor (GM-CSF) to treat different bacterial and viral infections with the identical targeted therapy [17].

To this end, the conclusions of the symposium pointed out that despite the heterogeneities between different pediatric lung diseases and even between different clinical phenotypes within one disease, the commonalities of major pathomechanisms highly encourage a comprehensive concept to elucidate the frontiers in science to the different pediatric lung diseases within a bundled interdisciplinary approach. Learning from the others' cohorts and experimental results cannot only broaden the horizon but speed up the development and introduction of new and more specific therapies into the clinics to all children with pediatric lung diseases. We want to thank all speakers for their excellent presentations during the symposium and for their important contributions to this special edition.

Received: 21 July 2016 Accepted: 21 July 2016

Published online: 27 July 2016

\section{References}

1. Seeger W, Welte T, Eickelberg O, Mall M, Rabe KF, Keller B, Winkler S, Koller U (2012) The German Centre for Lung Research—-translational research for the prevention, diagnosis and treatment of respiratory diseases. Pneumologie 66:464-469

2. Soriano JB, Paton J, Martin Burrieza F, Bill W, Pannetier C, Aliberti S, Adcock IM, Wagers S, The MGB, ERS (2016) Research agency: the beginning. Eur Respir J 47:1017-1023

3. Koenigshoff M (2014) The new back to basics section: emerging concepts in basic and translational medicine. Eur Respir J 44:297-298

4. Chao CM, Moiseenko A, Zimmer KP, Bellusci S (2016) Alveologenesis: key cellular players and fibroblast growth factor 10 signaling. Mol Cell Pediatr 3:17

5. Nardiello C, Morty RE (2016) MicroRNA in late lung development and bronchopulmonary dysplasia: the need to demonstrate causality. Mol Cell Pediatr 3:19

6. Shahzad T, Radajewski S, Chao CM, Bellusci S, Ehrhardt H (2016) Pathogenesis of bronchopulmonary dysplasia: when inflammation meets organ development. Mol Cell Pediatr 3:23

7. Marquez HA, Cardoso WV (2016) Vitamin A-retinoid signaling in pulmonary development and disease. Mol Cell Pediatr. doi:10.1186/s40348-016-0054-6

8. Hütten MC, Wolfs TG, Kramer BW (2016) Can the preterm lung recover from perinatal stress? Mol Cell Pediatr 3:15

9. Mueller M, Wolfs TG, Schoeberlein A, Gavilanes AW, Surbek D, Kramer BW (2016) Mesenchymal stem/stromal cells-a key mediator for regeneration after perinatal morbidity? Mol Cell Pediatr 3:6

10. Möbius MA, Rüdiger M (2016) Mesenchymal stromal cells in the development and therapy of bronchopulmonary dysplasia. Mol Cell Pediatr 3:18

11. Meiners S, Hilgendorff A (2016) Early injury of the neonatal lung contributes to premature lung aging-a hypothesis. Mol Cell Pediatr 3:24

12. Kabesch M (2016) The early origins of asthma and allergy. Mol Cell Pediatr. doi:10.1186/s40348-016-0056-4

13. Landgraf-Rauf K, Anselm B, Schaub B (2016) The puzzle of immune phenotypes of childhood asthma. Mol Cell Pediatr. doi:10.1186/s40348-016-0057-3

14. Wagner C, Schultz C, Mall M (2016) Neutrophil elastase and matrix metalloproteinase 12 in cystic fibrosis lung disease. Mol Cell Pediatr. doi:10.1186/s40348-016-0053-7
15. Hector A, Frey N, Hartl D (2016) Update on host-pathogen interactions in cystic fibrosis lung disease. Mol Cell Pediatr 3:12

16. Blaas D, Fuchs R (2016) Mechanism of human rhinovirus infections. Mol Cell Pediatr 3:21

17. Rösler B, Herold S (2016) Lung epithelial GM-CSF improves host defense function and epithelial repair in influenza virus pneumonia-a new therapeutic strategy? Mol Cell Pediatr. doi:10.1186/s40348-016-0055-5

\section{Submit your manuscript to a SpringerOpen ${ }^{\circ}$ journal and benefit from:}

- Convenient online submission

- Rigorous peer review

- Immediate publication on acceptance

- Open access: articles freely available online

- High visibility within the field

- Retaining the copyright to your article

Submit your next manuscript at $>$ springeropen.com 